\title{
Surgical outcomes of patients with non-small cell lung cancer following neoadjuvant treatment
}

\author{
Neoadjuvant tedavi sonrası küçük hücreli dışı akciğer kanseri olan hastaların cerrahi sonuçları
}

Ilhan OCAKCIOGLU, Levent ALPAY, Nezih Onur ERMERAK, Hakan KIRAL, Cagatay TEZEL, Volkan BAYSUNGUR, Irfan YALCINKAYA

\begin{abstract}
Objective: Although, anatomical resection of non-small cell lung cancer (NSCLC) following neoadjuvant therapy is still controversial, it is a widely accepted approach for thoracic surgery practice. The aim of this study is to briefly evaluate clinical results, long term survival, and factors affecting survival of the patients with locally advanced NSCLC, pancoast tumour and lung cancer with solitary brain metastasis, who have been operated at our institution following neoadjuvant therapy.

Materials and Method: Between March 2006 and March 2012, 70 patients with NSCLC diagnosis who underwent anatomic pulmonary resection following neoadjuvant therapy were included in the study.

Results: A three year survival (39\%) and a 5-year survival (29\%) were $16 \pm 6.8$ and $37 \pm 9.89$ months, respectively. The mean survival was found to be $37.15 \pm 3.06$ months. When survival rate was evaluated according to localization of tumor, it was lower in central and left upper lobe tumors compared to other anatomical localizations $(\mathrm{P}=0.042)$. The mean 5 -year survival times were $50.00 \pm 5.65$ months in stage 0 patients, $35.39 \pm 5.85$ months in stage 1 patients, $37.40 \pm 6.89$ months in stage 2 patients and $21.44 \pm 3.10$ months in stage 3 patients.

Conclusion: We can achieve significant survival results by the anatomical pulmonary resection following neoadjuvant therapy.
\end{abstract}

Keywords: Non-small cell lung cancer, Neoadjuvant therapy, Chemotherapy, Radiotherapy, Surgery

Ilhan Ocakcioglu ( $\varangle)$, Nezih Onur Ermerak

Department of Thoracic Surgery, School of Medicine, Marmara University, Pendik, Istanbul, Turkey

e-mail:ilhanocakcioglu@hotmail.com

Levent Alpay, Hakan Kiral, Cagatay Tezel, Volkan Baysungur, Irfan Yalcinkaya

Thoracic Surgery Clinic, Sureyyapasa Chest Diseases and Thoracic Surgery Training and Research Hospital, Maltepe, Istanbul, Turkey

Submitted / Gönderilme: 26.05 .2018

Accepted/Kabul: 01.08.2018
ÖZ

Amaç: Neoadjuvan tedaviyi takiben küçük hücreli dışı akciğer kanseri (KHDAK)'nin anatomik rezeksiyonu halen tartışmalı olsa $\mathrm{da}$, torasik cerrahi uygulamada yaygın kabul gören bir yaklaşımdır. $\mathrm{Bu}$ çalışmanın amacı, neadjuvan tedaviyi takiben kurumumuzda cerrahi operasyon uygulanan lokal ileri evre KHDAK'i, pancoast tümörü ve soliter beyin metastazı olan akciğer kanseri hastalarının klinik sonuçlarını, uzun dönem sağkalımını ve sağkalımı etkileyen faktörleri kısaca değerlendirmektir.

Gereç ve Yöntem: Mart 2006 ve Mart 2012 tarihleri arasında neoadjuvan tedaviyi takiben anatomik pulmoner rezeksiyon uygulanan 70 KHDAK tanılı hasta çalışmaya alındı.

Bulgular: Üç yıllık sağkalım (\% 39) ve 5 yıllık sağkalım (\% 29) sirasiyla $16 \pm 6,8$ ve $37 \pm 9,89$ ay idi. Ortalama sağ kalım $37,15 \pm 3,06$ ay olarak bulundu. Sağkalım oranı tümörün anatomik lokalizasyonuna göre değerlendirildiğinde santral ve sol üst lob tümörlerinde daha düşüktü $(\mathrm{P}=0,042)$. 5 y1llık ortalama sağkalım süreleri evre 0 hastalarda 50,00 $\pm 5,65$ ay, evre 1 hastalarda $35,39 \pm 5,85$ ay, evre 2

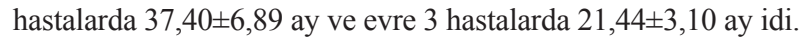

Sonuç: Neoadjuvan tedaviyi takiben anatomik pulmoner rezeksiyon ile önemli sağkalım sonuçları elde edebiliriz.

Anahtar kelimeler: Küçük hücreli dışı akciğer kanseri, Neoadjuvan tedavi, Kemoterapi, Radyoterapi, Cerrahi

\section{Introduction}

Although, anatomical resection of non-small cell lung cancer (NSCLC) following neoadjuvant therapy is still controversial, it is a widely accepted approach for thoracic surgery practice. The use of trimodality treatment has increased after publications supporting neoadjuvant therapy $[1,2]$.

Oncological control of locally advanced stage III NSCLC is extremely difficult, despite all new treatment modalities. Recent studies have shown that neoadjuvant chemoradiotherapy positively affects the rates of resectability in patients with locally advanced stage III NSCLC and offers better results than the surgery-only groups [3]. Publications 
regarding the effect of neoadjuvant therapy on the pancoast tumours also favored trimodality treatment $[4,5]$.

The aim of this study is to briefly evaluate clinical results, long term survival, and factors affecting survival of the patients with locally advanced NSCLC, pancoast tumour and lung cancer with solitary brain metastasis, who have been operated at our institution following neoadjuvant therapy.

\section{Materials and Methods}

Between March 2006 and March 2012, 70 patients with NSCLC diagnosis who underwent anatomic pulmonary resection following neoadjuvant therapy were retrospectively reviewed. Ninety-one patients undergoing neoadjuvant therapy were included in the study, but only $76.9 \%(\mathrm{n}=70)$ of them underwent anatomical pulmonary resection. Twenty-one patients were excluded from the study due to the progression or no change on their nodal status and size of the tumour despite the neoadjuvant treatment.

The inclusion criteria were as follows: 1. radiological or histological diagnosis of a single-station mediastinal lymph node involvement, 2. centrally located or locoregional advanced stage NSCLC, 3 pancoast tumour, 4 synchronous solitary brain metastasis.

The exclusion criteria were: 1. chemotherapy or radiotherapy for other malignancies, 2. adjuvant chemotherapy and/or radiotherapy, 3. presence of unresectable tumor despite neoadjuvant therapy, 4. psychologically unsuitability for completing the regimen.

The mediastinal status of the patients was confirmed by mediastinoscopy for histological diagnosis and radiologically interpreted by computed tomography (CT) or positron emission tomography (PET) before neoadjuvant treatment.

\section{Neoadjuvant chemotheraphy regimen}

Cisplatin $(60-75 \mathrm{mgr} / \mathrm{m} 2)+$ docetaxel $(75 \mathrm{mgr} / \mathrm{m} 2)$ or cisplatin $(60-75 \mathrm{mgr} / \mathrm{m} 2)+$ gemcitabin $(1 \mathrm{gr} / \mathrm{m} 2)$ in standard treatment protocol was received as total 6 cycles, of which 3 cycles preoperatively and 3 cycles postoperatively.

\section{Neoadjuvant radiotheraphy regimen}

4000-4600 cGy of radiotheraphy with 200 cGy daily fraction dosages was performed preoperatively for clinically
T4 (Ct4) tumours and total dosage was completed to 60006600 cGy postoperatively. The protocol was different for pancoast cases. $4600 \mathrm{cGy}$ of radiotheraphy with $250 \mathrm{cGy}$ daily fraction dosages was performed preoperatively and total dosage was completed to $6600-7000$ postoperatively.

\section{Evaluation after neoadjuvant treatment}

All cases were re-evaluated according to the surgical and radiological aspects after the neoadjuvant treatment. CT and PET were used for the majority of the cases but remediastinoscopy was required in few selected patients for the evaluation. Patients who had no lymph node invasion or metastasis were selected for anatomical pulmonary resection.

All data were evaluated in terms of age, sex, comorbidities, smoking, FEV1 value, localization of the tumour, type of the resection, regimen type, clinical staging before and after treatment, pathological staging after surgery, histological type, clinical response, morbidity, mortality, lenght of hospital stay, recurrence, clinical follow-up and survival. This study was approved by the Institutional Ethics Committee.

\section{Statistical Analysis}

Descriptive statistics for continuous variables were reported as means and standard deviation (SD) with $95 \%$ confidence interval (CI). Apart from descriptive statistical methods, Kruskal Wallis was used for the comparison between groups. The Mann-Whitney U test was used to compare differences between two independent groups. Wilcoxon sign test was used for intra-group comparisons. Chi-square test, Yates corrected chi-square test and Fisher's exact test was used in the comparison of qualitative data. KaplanMeier analysis and Log Rank (Mantel-Cox) were used for survival analysis. In this study, the maximum type I error was 0.05 , and the level of significance was accepted as $\mathrm{P}<$ 0.05. All analyses were performed using Number Cruncher Statistical System (NCSS) and Power Analysis and Sample Size (PASS) statistical software (Utah, USA).

\section{Results}

Study was designed with 91 patients receiving neoadjuvant treatment. Unfortunately, 21 inoperable patients who had progression despite neoadjuvant therapy were excluded from the study. The age of the patients varied from 41 to 76 
years (mean $56.31 \pm 7.36$ years). Sixty-five of the cases were male $(92.9 \%)$ and $5(7.1 \%)$ were female.

In terms of neoadjuvant treatment, fifty patients (71.4\%) were treated with chemotherapy, 11 patients with $(15.7 \%)$ chemoradiotherapy, and 9 patients with (12.9\%) radiotherapy. Chemotherapy and radiotherapy regimens are shown in Table I.

Table I. Chemotherapy and radiotherapy regimens

\begin{tabular}{llll}
\hline & Min-Max & Mean \pm SD \\
\hline Radiotherapy Dosage & $30.00-66.00$ & $47.20 \pm 10.23$ \\
& & $\mathrm{~N}$ & $\%$ \\
\hline Chemotherapy & 2 & 3 & 4.9 \\
Cycle & 3 & 51 & 83.6 \\
& 4 & 3 & 4.9 \\
& 6 & 4 & 6.6 \\
\hline Type of & Cisplatin-Docetaxel & 52 & 85.2 \\
Chemotherapy & Cisplatin-Gemcitabin & 6 & 9.8 \\
& Cisplatin-Paclitaxel & 2 & 3.2 \\
& Cisplatin & 1 & 1.6 \\
\hline
\end{tabular}

The exclusion of N2 disease after neoadjuvant therapy was provided by mediastinoscopy in $37(53 \%)$ patients and radiological evaluation in $33(47 \%)$ patients. Clinical staging is described in Table II.

Table II. Clinical staging

\begin{tabular}{|c|c|c|c|c|c|}
\hline & & \multicolumn{2}{|c|}{$\begin{array}{l}\text { Before Neoadjuvant } \\
\text { Therapy }\end{array}$} & \multicolumn{2}{|c|}{$\begin{array}{l}\text { After Neoadjuvant } \\
\text { Therapy }\end{array}$} \\
\hline & & $\mathrm{N}$ & $\%$ & $\mathrm{~N}$ & $\%$ \\
\hline \multirow{5}{*}{$\mathrm{T}$} & T0 & - & - & 24 & 34.2 \\
\hline & $\mathrm{T} 1$ & 9 & 12.8 & 20 & 28.5 \\
\hline & $\mathrm{T} 2$ & 22 & 31.4 & 17 & 24.2 \\
\hline & T3 & 24 & 34.2 & 9 & 12.8 \\
\hline & $\mathrm{T} 4$ & 15 & 21.4 & - & - \\
\hline \multirow{4}{*}{$\mathrm{N}$} & N0 & 17 & 24.3 & 26 & 57.8 \\
\hline & N1 & 2 & 2.9 & 1 & 2.2 \\
\hline & N2 & 50 & 71.4 & 17 & 37.8 \\
\hline & N3 & 1 & 1.4 & 1 & 2.2 \\
\hline \multirow{2}{*}{ M } & M0 & 67 & 95.5 & 44 & 100 \\
\hline & M1 & 3 & 4.5 & - & - \\
\hline \multirow{4}{*}{$\begin{array}{l}\text { Clinical } \\
\text { Staging }\end{array}$} & $2 \mathrm{~B}$ & 7 & 10.0 & & \\
\hline & $3 \mathrm{~A}$ & 54 & 77.1 & & \\
\hline & $3 B$ & 6 & 8.6 & & \\
\hline & 4 & 3 & 4.3 & & \\
\hline
\end{tabular}

T:Tumour, N: Nodal cT4:clinically T4, M: Metastasis
Tumors were located at the right upper lobe in 30 patients (43.5\%), hilar in 16 patients (23.2\%), left upper lobe in 15 patients $(21.7 \%)$, left lower lobe in 5 patients $(7.2 \%)$ and right lower lobe in 3 patients (4.3\%).

Resection following neoadjuvant treatment was planned for 30 patients $(42.8 \%)$ with pathological N2 invasion, 19 patients $(27.1 \%)$ with radiological N2 invasion, 10 patients (14.2\%) with cT4 tumor, 8 patients (11.4\%) with pancoast tumour, and 3 patients with solitary brain metastasis. Lobectomy was conducted in 37 patients (52.9\%), pneumonectomy in 22 patients $(31.4 \%)$ and bilobectomy in 11 patients $(15.7 \%) .6$ of the patients $(8.6 \%)$ underwent sleeve resection.

On TNM staging after resection, there were 13 patients in stage IA (18.5\%), 7 in stage IB (10\%), 9 in stage IIA (12.8\%), 13 in stage IIB (18.5\%), 18 in stage IIIA (25.7\%) and 1 in stage IIIB (1.4\%). The pathological results of the other 9 patients (12.8\%) were reported as complete response. Of 70 patients included, 65 patients $(92.6 \%)$ had R0 resection and 5 patients had R1 resection. No tumor was detected in the histological examination of 9 patients (12.8\%) due to the complete response to treatment. Pathological staging is shown in Table III.

Table III. Pathological staging

\begin{tabular}{|c|c|c|c|}
\hline & & \multicolumn{2}{|c|}{ After Surgery } \\
\hline & & $\mathrm{N}$ & $\%$ \\
\hline \multirow{7}{*}{$\mathrm{T}$} & $\mathrm{T} 0$ & 9 & 12.8 \\
\hline & $\mathrm{T} 1 \mathrm{~A}$ & 18 & 25.7 \\
\hline & $\mathrm{T} 1 \mathrm{~B}$ & 6 & 8.5 \\
\hline & $\mathrm{T} 2 \mathrm{~A}$ & 10 & 14.2 \\
\hline & $\mathrm{T} 2 \mathrm{~B}$ & 1 & 1.4 \\
\hline & T3 & 20 & 28.5 \\
\hline & $\mathrm{T} 4$ & 6 & 8.5 \\
\hline \multirow{3}{*}{$\mathrm{N}$} & N0 & 45 & 64.3 \\
\hline & N1 & 14 & 20.0 \\
\hline & $\mathrm{N} 2$ & 11 & 15.7 \\
\hline M & M0 & 70 & 100 \\
\hline \multirow{7}{*}{$\begin{array}{l}\text { Pathological } \\
\text { Staging }\end{array}$} & 0 & 9 & 12.8 \\
\hline & $1 \mathrm{~A}$ & 13 & 18.5 \\
\hline & 1B & 7 & 10 \\
\hline & $2 \mathrm{~A}$ & 9 & 12.8 \\
\hline & $2 \mathrm{~B}$ & 13 & 18.5 \\
\hline & $3 \mathrm{~A}$ & 18 & 25.7 \\
\hline & $3 \mathrm{~B}$ & 1 & 1.4 \\
\hline
\end{tabular}

T:Tumour, N: Nodal cT4:clinically T4, M: Metastasis 
When the pathological staging after neoadjuvant therapy was compared with the clinical staging before neoadjuvant therapy, there were complete response in 9 patients (13\%), partial response in 40 patients $(57 \%)$, no response in 20 patients $(29 \%)$, and progression in one patient $(1 \%)$.

The 30-day morbidity rate was $36 \%$. The most common causes of major morbidity were pneumonia $(11.4 \%)$ and postoperative bleeding (10\%). The most common cause of minor morbidity was prolonged air leak (12.8\%). No statistical difference was detected between the types of neoadjuvant treatment and air leak $(\mathrm{P}>0.05)$. The postoperative 30 -day mortality rate was $4 \%$ ( 3 cases). No statistical difference was detected between type of neoadjuvant therapy, type of resection and postoperative early mortality $(\mathrm{P}>0.05)$. Intensive care unit (ICU) was required for 14 patients $(20 \%)$ in the postoperative period. No statistical difference was detected between the ICU necessity and the type of the resection $(\mathrm{P}>0.05)$.

Mean length of the hospital stay was $8.851 \pm 1.10$ days (2-74 days) and mean follow-up period was $18.86 \pm 18.28$ months (1-60.5). Recurrence was detected in 21 patients (30\%) during the follow-up period. Fourteen of these patients $(20 \%)$ were distant metastasis, and $7(10 \%)$ were local metastasis. Recurrence rate was high in patients who received chemotherapy as neoadjuvant therapy and was statistically significant $(\mathrm{P}<0.05)$. There was no statistically significant difference in patients who received radiotherapy or chemoradiotherapy $(\mathrm{P}>0.05)$. In terms of resection type, recurrence rate was statistically significant only in the patients who underwent lobectomy $(\mathrm{P}<0.05)$.

During the follow-up period, we experienced cancer related mortality in $33(47 \%)$ patients and non-cancer mortality in 3 patients (4\%). A 3-year survival time $(39 \%)$ and 5-year survival time (29\%) were $16 \pm 6.8$ and $37 \pm 9.89$ months, respectively. Mean survival time was $37.15 \pm 3.06$ months. When the survival rates were evaluated according to localization of the tumor, the central and left upper lobe tumours had lower survival rates than the others $(\mathrm{P}=0.042)$.

In terms of neoadjuvant indication and survival, the mean survival was $43.99 \pm 8.54$ months in cT4, 37,48 $\pm 4,17$ months in N2 disease, $22.05 \pm 9.34$ months in pancoast and $16.33 \pm 3.08$ months in solitary brain metastasis. Neodajuvant indication and survival is shown in Figure 1.

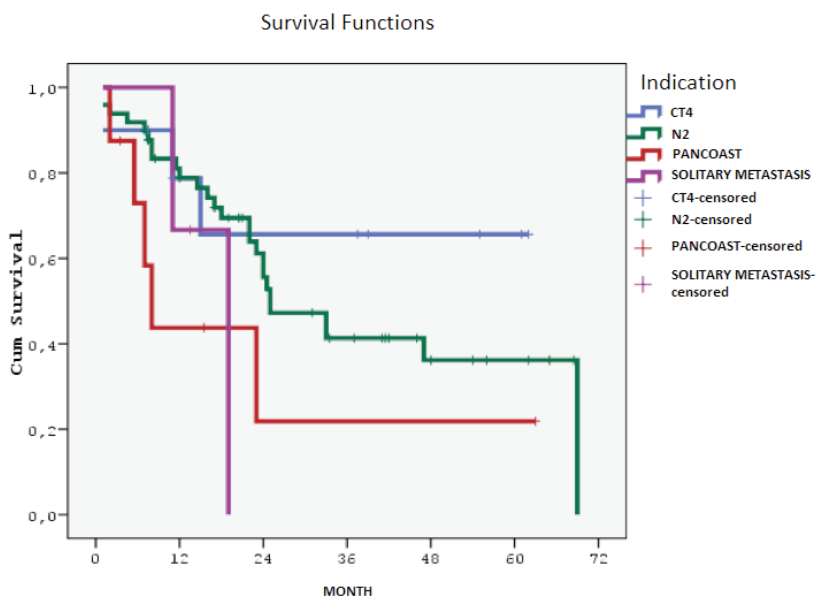

Figure 1. Survival rates according to indication

Regarding the relation between neadjuvant treatment type and survival; the mean survival was $40.67 \pm 4.08$ months in chemotherapy, $24.49 \pm 9.96$ months in radiotherapy and $19.88 \pm 4.25$ months in chemoradiotherapy. Neodajuvant treatment type and survival is shown in Figure 2.

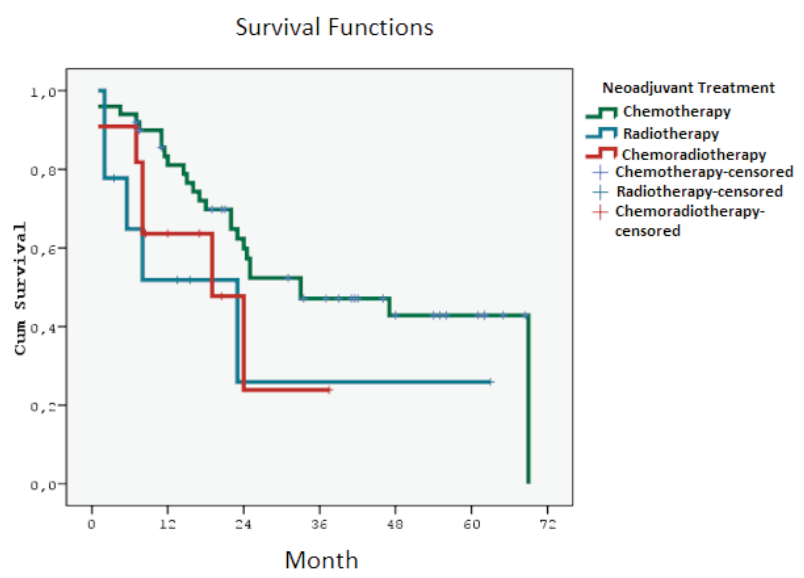

Figure 2. Relationship between type of neoadjuvant treatment and survival rate

If we examine the survival rates according to the type of resection, mean survival time was $33.35 \pm 4.59$ months in lobectomy, $40.81 \pm 7.0$ months in pneumonectomy and $36.39 \pm 6.89$ in bilobectomy. Mean survival was significantly lower in left pneumonectomy (18.08 \pm 2.55 months) in comparison to right pneumonectomy (56.18 \pm 9.70 months) $(\mathrm{P}=0.021)$.

In the evaluation of a 5-year follow-up period; mean survial time was $50.00 \pm 5.65$ months in stage $0.35 .39 \pm 5.85$ months in stage $1,37.40 \pm 6.89$ months in stage 2 , and 
21.44 \pm 3.10 months in stage 3. Pathological staging and survival is shown in Figure 3.

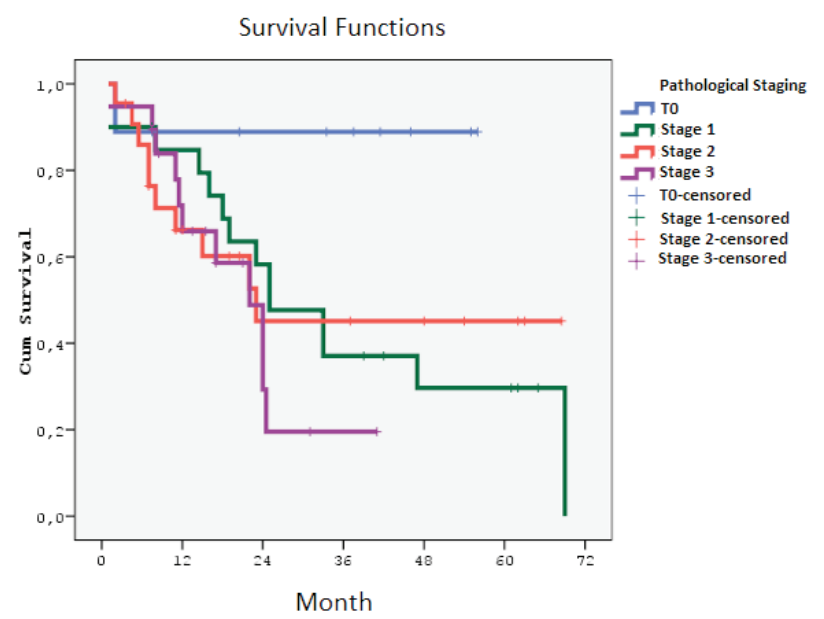

Figure 3. Pathological staging and survival rates

\section{Discussion}

The determination of appropriate patients to benefit from surgical resection after neoadjuvant therapy is still controversial. Some authors reported that clinical response after neoadjuvant treatment and the eradication of the disease with the operation were sufficient for the surgical outcome $[6,7]$.

It is put forward that neoadjuvant treatment increases the resectability rates by taking part in the reduction of the tumour size and helping in annihilation of the micrometastatic disease. It is also important that neoadjuvant treatment can be performed in the highest dosages and easily tolerated when compared to adjuvant treatment [8]. It is difficult to determine the proper treatment modality because of having clinically heterogeneous pattern. Radiologically suspicious or histologically proven N2 disease, inoperable disease due to tumor size or localization, pancoast tumor or solitary brain metastasis were included in the study.

Resection of N2 disease after neoadjuvant chemotherapy increases long-term survival compared to medical treatment alone [7,9]. Cerfolio and colleagues reported that a 5-year survival rate after resection of non-suspicious N2 disease following neoadjuvant treatment was $42 \%$ [10]. In our study, a 5-year survival rate for N2 disease patients who underwent resection following neoadjuvant treatment was $46.9 \%$.
Takeda et al., published a study reporting that tumour localization was not effective on survival and prognosis [9]. In contrast to this publication, the survival rates of the central and left upper lobe tumors were found to be significantly lower in our study $(\mathrm{P}=0.042)$.

The addition of preoperative radiotherapy to chemotherapy is thought to provide more successful outcome and more aggressive locoregional control than neoadjuvant chemotherapy alone [6]. High preoperative radiation dose increases the incidence of complete response $[10,11]$. Jacklitsch and colleagues pointed out that complete resection following neoadjuvant treatment have the key role in the increased long-term survival [12]. In our study, we did not detect a statistical difference between the types of neoadjuvant treatments and survival rates $(\mathrm{P}=0.122)$. Although, it was not statistically significant, survival rates were higher in the patients who received neoadjuvant chemotherapy alone.

In terms of survival rates according to the type of resection, no statistical difference was detected in our study $(\mathrm{P}=0.579)$. Deslauriers and colleagues reported that patients with N2 disease who underwent sleeve lobectomy or pneumonectomy after chemoradiotherapy had poor prognosis and unsatisfactory results [13]. Despite the high morbidity and mortality reports of pneumonectomy in the previous publications, we did not detect any results favoring high mortality, morbidity and poor prognosis in our study. In contrast to related literature, we found out that survival rates were higher in the pneumonectomy patients. Kim et al., published that although there was no statistically significant difference in terms of survival between the lobectomy and the pneumonectomy patients, lobectomy patients had more survival time than the pneumonectomy patients [14]. Some authors also reported that right pneumonectomy patients had higher postoperative morbidity rates without the statistical reflection on the survival rates [14-16]. When pneumonectomy patients were evaluated in terms of the side; contrary to current opinion, our study showed better survival in right pneumonectomy $(\mathrm{P}=0.021)$. In our belief; the reason for this outcome comes from performing more detailed preoperative evaluation of patients who are planned for right pneumonectomy.

Cerfolio and friends reported that most common major morbidities were pneumonia and respiratory distress [10]. We found out that pneumonia and hemorrhage were the most common major morbidities. 
A 5-year survival rate after primary surgical resection in stage IIIA patients with N2 nodal invasion was $17-20 \%$. It is reported by many publications that a 5 -year survival was increased up to $19-45 \%$ by the help of the multimodality treatment. International Association for the Lung Cancer Staging Commitee published a multi-center study about patients with $\mathrm{N} 2$ and $\mathrm{N} 1$ disease who recevied neoadjuvant treatment. In the comparison of the patients with single N2 nodal disease and $\mathrm{N} 1$ disease who received neoadjuvant therapy, the same survival rates were achieved [17]. Borri and colleagues reported that long-term survival was only achieved in the patients receiving neoadjuvant therapy [18]. Our study revealed similar results with the other series focusing on multimodality treatment in NSCLC patients. Some studies reported that a 5-year survival was $3-10 \%$ in stage III patients receiving adjuvant chemotherapy $[11,19]$. Borri and colleagues advocated that even with R1 resection, the patients had better survival rates $(22 \%)$ in comparison to adjuvant chemotherapy [18]. Decaluwe et al., published a series of 92 patients who underwent resection following neoadjuvant treatment and reported complete resection rate of $68 \%$. When compared to this publication, our study revealed a complete resection rate of $95 \%$ [20].

The increase in the stage of the disease results with decrease in the survival rates [14]. Similarly, there was a decrease in survival curve in our study. Kim and colleagues found out a significant difference between the pathological $\mathrm{T}$ variant and the survival [14]. When we evaluated T variants in our study; T1 and T2 had the similar mean survival times but $\mathrm{T} 3$ and $\mathrm{T} 4$ patients showed significant decrease in terms of mean survival times.

In the evaluation of $\mathrm{N}$ variant, mean survival time was $37.54 \pm 4.35$ months in patients with N0 disease, $44.77 \pm 8.40$ months in patients with $\mathrm{N} 1$ disease and $25.68 \pm 3.63$ months in patients with $\mathrm{N} 2$ disease. We believe that increase in the survival time of N1 patients may be related to the lack of subgroups. We did not detect any statistical difference when we compared $\mathrm{N}$ status and survival rates $(\mathrm{P}=0.969)$. Researchers believe that $\mathrm{N} 2$ disease is the continuation of the N1 disease and both of them need adjuvant chemotherapy in the postoperative period. In the light of this general opinion; when they evaluate the comparison between $\mathrm{N}$ status and survival rates, they count $\mathrm{N} 1+\mathrm{N} 2$ patients as one group $(\mathrm{N} 1+\mathrm{N} 2)$ and compare them with $\mathrm{N} 0$ disease. One study detected a significant difference in survival between patients with $\mathrm{N} 0$ and $\mathrm{N} 1$ positive and patients with $\mathrm{N} 2$ positive. According to the results of this study, a 5-year survival rate was $53 \%$ in patients with $\mathrm{N} 0$ or $\mathrm{N} 1$, and $10-16$ $\%$ in patients with $\mathrm{N} 2$ positive $[21,22]$. We did not detect a similar relationship in our study. Some authors reported that multiple N2 lymph node positivity adversely affected the survival rates. Unfortunately, these studies did not include patients who received neoadjuvant theraphy [22,23]. Port and colleagues presented that they could not detect any significant difference in terms of survival rates between patients with multiple $\mathrm{N} 2$ nodal invasion and patients with single N2 nodal invasion [7]. We also could not detect any significancy in our study, either.

\section{Conclusion}

In locally advanced NSCLC, we can obtain considerable survival results by the help of the anatomical resection following neoadjuvant theraphy. However, surgical difficulties due to the neoadjuvant therapy, complexity in the designation of the real stage, toxicity of the treatment modality and difficulties during follow-up period are the limitations and the challanges of the multimodality treatment approach.

\section{References}

1. Faber LP, Kittle CF, Warren WH, et al. Preoperative chemotherapy and irradiation for stage III non-small cell lung cancer. Ann Thorac Surg 1989;47: 669-77. doi: 10.1016/0003-4975(89)90115-X

2. Skarin A, Jochelson M, Sheldon T, et al. Neoadjuvant chemotherapy in marginally resectable stage III M0 nonsmall cell lung cancer: long-term follow-up in 41 patients. $\mathrm{J}$ Surg Oncol 1989;40: 266-74. doi: 10.1002/jso.2930400413

3. Roth JA, Fossella F, Komaki R, et al. A randomized trial comparing preoperative chemotherapy and surgery and surgery alone in resectable III A non-small cell lung cancer. J Natl Cancer Inst 1994;86: 673-80. doi: 10.1093/jnci/86.9.673

4. Rusch VW, Giroux DJ, Kraut MJ, et al. Induction chemoradiation and surgical resection for non-small cell lung carcinomas of the superior sulcus: initial results of Southwest Oncology Group Trial 9416 (Intergroup Trial 0160). J Thorac Cardiovasc Surg 2001;121:472-83. doi: 10.1067/ mtc.2001.112465

5. Albain K, Swann R, Rusch V. Phase III study of concurrent chemotherapy and radiotherapy (CT/RT) versus CT/RT followed by surgical resection for stage IIIA (pN2) nonsmall-cell lung cancer (NSCLC): Outcomes update of North American Intergroup 0139 (RTOG 9309) J Clin Oncol 2005;23:624S. doi: 10.1200/jco.2005.23.16_suppl.7014

6. Bueno R, Richards WG, Swanson SJ, et al. Nodal stage after induction therapy for stage IIIA lung cancer determines 
patient survival. Ann Thorac Surg 2000;70: 1826-31. doi: 10.1016/S0003-4975(00)01585-X

7. Port JL, Korst RJ, Lee PC, et al. Surgical resection for residual N2 disease after induction chemotherapy. Ann Thorac Surg 2005;79:1686-90. doi: 10.1016/j.athoracsur.2004.10.057

8. Spira A, Ettinger DS. Multidisciplinary management of lung cancer. N Engl J Med 2004;350:379-92. doi: 10.1056/ NEJMra035536

9. Takeda S, Maeda H, Okada T, et al. Results of pulmonary resection following neoadjuvant therapy for locally advanced (IIIA-IIIB) lung cancer. Eur J Cardiothorac Surg 2006;30:184-9. doi: 10.1016/j.ejcts.2006.03.054

10. Cerfolio RJ, Bryant AS. Survival of patients with unsuspected N2 (stage IIIA) nonsmall-cell lung cancer. Ann Thorac Surg 2008;86:362-7. doi: 10.1016/j.athoracsur.2008.04.042.

11. Carretta A, Ciriaco P, Melloni G, et al. Results of surgical treatment after neoadjuvant chemotherapy for stage III nonsmall cell lung cancer. World J Surg 2008; 32:2636-42. doi: 10.1007/s00268-008-9774-7.

12. Jaklitsch MT, J.E. Herndon JE, DeCamp MM, et al. Nodal downstaging predicts survival following induction chemotherapy for stage IIIA (N2) non-small cell lung cancer in CALGB protocol \#8935. J Surg Oncol 2006;94:599-606. doi: $10.1002 /$ jso. 20644

13. Deslauriers J, Grégoire J, Jacques LF, et al. Sleeve lobectomy versus pneumonectomy for lung cancer: a comparative analysis of survival and sites or recurrences. Ann Thorac Surg 2004;77:1152-56. doi:10.1016/j.athoracsur.2003.07.040

14. Kim AW, Liptay MJ, Bonomi P, et al. Neoadjuvant chemoradiation for clinically advanced non-small cell lung cancer: An analysis of 233 patients. Ann Thorac Surg 2011;92:233-43. doi: 10.1016/j.athoracsur.2011.03.001

15. Martin J, Ginsberg RJ, Abolhoda A, et al. Morbidity and mortality after neoadjuvant therapy for lung cancers: The risk of right pneumonectomy. Ann Thorac Surg 2001; 72:114954. doi: 10.1016/S0003-4975(01)02995-2

16. Van Schil P, Van Meerbeeck J, Kramer G, et al. Morbidity and mortality in the surgery arm of EORTC 08941 trial. Eur Respir J 2005;26: 192-7. doi: 10.1183/09031936.05.00127204

17. Bakir M, Fraser S, Routledge T, et al. Is surgery indicated in patients with stage IIIa lung cancer and mediastinal nodal involvement? Interact Cardiovasc Thorac Surg 2011;13:30310. doi: 10.1510 /icvts.2011.267872

18. BorriA, Leo F, Veronesi G, et al. Extended pneumonectomy for non-small cell lung cancer: morbidity, mortality, and longterm results. J Thorac Cardiovasc Surg 2007;134:1266-72. doi:10.1016/j.jtcvs.2007.01.021

19. Marino P, Preatoni A, Cantoni A. Randomized trials of radiotherapy alone versus combined chemotherapy and radiotherapy in stage IIIa and IIIb non-small cell lung cancer. A meta-analysis. Cancer 1995;76:593601. doi:10.1002/1097-0142(19950815)76:4<593::AIDCNCR2820760409>3.0.CO;2-N

20. Decaluwé H, De Leyn P, Vansteenkiste J, et al. Surgical multimodality treatment for baseline resectable stage IIIA-N2 non-small cell lung cancer. Degree of mediastinal lymph node involvement and impact on survival. Eur J Cardiothorac Surg 2009; 36:433-9. doi: 10.1016/j.ejcts.2009.04.01

21. Tanaka F, Yanagihara K, Otake $Y$ et al. Prognostic factors in resected pathologic $(p-)$ stage IIIA-N2, non-small-cell lung cancer. Ann Surg Oncol 2004;11:612-8. doi: 10.1245/ ASO.2004.07.013

22. Van Raemdonck DE, Schneider A, Ginsberg RJ. Surgical treatment for higher stage non-small cell lung cancer. Ann Thorac Surg 1992;54:999-1013. doi: 10.1016/00034975(92)90677-V

23. Rowell NP, O'rourke NP. Concurrent chemoradiotherapy in non-small cell lung cancer. Cochrane Database Syst Rev 2004 Oct 18; (4):CD002140. 